\title{
Studies on Integrated Nutrient Management on Yield and Quality of Chilli (Capsicum annum L.)
}

\author{
Samsangheile Nchang ${ }^{1}$, S.P. Kanaujia ${ }^{1}$, Santosh Lal ${ }^{1 *}$, \\ Vinit Kumar Meena ${ }^{2}$ and Babu Singh Tanwar ${ }^{3}$
}

${ }^{1}$ Department of Horticulture, School of Agricultural Sciences and Rural Development, Medziphema Campus, Nagaland University, Nagaland - 797106, India

${ }^{2}$ Department of Horticulture, Rajasthan College of Agriculture, MPUAT, Udaipur, Rajasthan-313001, India

${ }^{3}$ Department of Horticulture, SHIATS, Allahabad, India

*Corresponding author

\section{A B S T R A C T}

A field experiment was carried out at the experimental farm of SASRD, Medziphema Campus, Nagaland University, during October, 2010 to May, 2011 using Randomized

Keywords

Chilli, INM, Chemical fertilizers, Organic manures,

Biofertilizers, Yield, Quality

Article Info

Accepted:

12 August 2018

Available Online:

10 September 2018
Block Design to evaluate the integrated effect of chemical fertilizers, organic manures and biofertilizers on yield and quality of chilli under the foothill condition of Nagaland. Results of the twelve treatment combination field experiment revealed that integrated application of chemical fertilizers, organic manures and biofertilizers significantly increased the yield and quality, characters of chilli over control. Apart from temperature, soil moisture and photoperiod, nutrition is one of the paramount factors which the reproductive development in chilli. Use of organic manures was suggested in pepper cultivation. The efficacies of Vermicompost, pig manure, poultry manure, farmyard manure, biofertilizer (Azospirillum and phosphotika), NPK etc, in improving quality of the plants and increasing the yield and quality of fruit was well documented. The use of organic manures corrects multiple deficiency and sectional elements improve physical, chemical and biological property of soil as well as number of fruit plant ${ }^{-1}$ (99.44), fruit weight $(3.30 \mathrm{~g})$, fruit length $(8.90 \mathrm{~cm})$, fruit diameter $(1.20 \mathrm{~cm})$, pod yield $\left(194.70 \mathrm{q} \mathrm{ha}^{-1}\right)$, TSS (5.10 ${ }^{\circ}$ Brix) and vitamin C (247.16 mg/100g) were recorded with the conjoint application of $50 \%$ NPK $+50 \%$ FYM + Biofertilizers.

\section{Introduction}

Chilli (Capsicum annuum L.) belongs to the family Solanaceae, grown for its fruit. It is one of the most important spice crops of the world and is widely cultivated throughout the warm, temperate, tropical and subtropical countries. Chilli was originated in tropical
America and its seeds were brought to Spain in 1493 by Columbus which rapidly spread in Europe.

It was introduced India by Portuguese during 16th century (Raju and Luckrose, 1991) and it is an indispensable spice essentially used in every Indian cuisine due to its pungency, 
spice, taste, appealing odour and flavour. Chilli fruits are rich source of Vitamin C, A and $\mathrm{E}$.

Chilli is famous for its pleasant aromatic flavour, pungency and high colouring substance. It is used very widely in culinary, pharmaceutical and beverage industries. Hence, chilli finds diverse utility as a spice, condiment, culinary supplement, medicine and vegetable, besides it is an important commercial crop. Chilli is cultivated worldwide on an area of 10 million ha with annual production of 8.75 million tonnes with an productivity of $8132 \mathrm{~kg}$ per ha (Anon., 2004). Hot chilli producing countries are India, China, Indonesia, Korea, Pakistan, Turkey and Srilanka. The mild chilli producing countries are Hungary, Spain, Romania and Bulgaria.

In India, chilli is grown on an area of 7.59 lakh ha with annual production of 12.89 lakh tonnes and productivity of $1698 \mathrm{~kg}$ per ha (Anon., 2005), which is considerably lower as compared to world's productivity. Though, chilli is grown in many states of our country, the major area lies in southern states viz., Andhra Pradesh, Karnataka, Maharashtra, Orissa and Tamilnadu which contribute 73 per cent of chilli production and 95 per cent of it is consumed within the country and five per cent is exported to other countries such as USA, Srilanka, Bangladesh, Nepal and Mexico.

IPNM aims at maintenance or adjustment of soil fertility and of plant nutrient supply to an optimum level for sustaining the desired crop productivity through optimization of the benefit from all possible sources of plant nutrients in an integrated manner (Roy and Ange, 1991). The integrated nutrient supply to an optimum level is possible only through judicious and efficient use of mineral fertilizers, organic manures, biofertilizers, green manures and crop residues (Tilak and Singh, 1996). Integrated nutrient management is technically sound, economically viable, socially acceptable, practically feasible and ecologically sound system of production (Chaubey et al., 2004). India has emerged today as the foremost producer and exporter of chillies contributing to almost one third of world production.

Chilli is grown mainly as a rain fed crop (kharif season). As an integrated crop, it is grown during rabi and summer seasons. Chilli requires adequate soil nutrient supply for its optimum production. As an emerging crop with respect to its improvement and production owing to its dollar earning potential, chemical fertilizers and other soil amendments will be needed for its profitable cultivation. The agro-climatic condition prevailing in the low hills of Nagaland have been found to be highly favourable for chilli cultivation.

\section{Materials and Methods}

\section{Experimental design}

The experiment was laid out in Randomized Block Design, with 12(twelve) treatments and 3(three) replications.

Design: RBD

Replication: 3

Variety: G-4 (Bhagyalakshmi)

Plot size: $1.8 \mathrm{~m} \times 1.5 \mathrm{~m}$

Spacing: $45 \mathrm{~cm} \times 30 \mathrm{~cm}$

Number of treatments: 12

\section{Treatments}

$\mathrm{T}_{1}-$ Control

$\mathrm{T}_{2}-\mathrm{FYM} 20 \mathrm{t} \mathrm{ha}^{-1}$

$\mathrm{T}_{3}$ - Pig manure $15 \mathrm{tha}^{-1}$ 
$\mathrm{T}_{4}$ - Vermicompost $10 \mathrm{tha}^{-1}$

$\mathrm{T}_{5}-100 \%$ NPK (100:60:60 $\left.\mathrm{kg} \mathrm{ha}^{-1}\right)$

$\mathrm{T}_{6}-75 \%$ NPK + biofertilizers (Azospirillum and phosphotika)

$\mathrm{T}_{7}-50 \% \mathrm{NPK}+50 \% \mathrm{FYM}$

$\mathrm{T}_{8}-50 \% \mathrm{NPK}+50 \%$ pig manure

$\mathrm{T}_{9}-50 \% \mathrm{NPK}+50 \%$ vermicompost

$\mathrm{T}_{10}-50 \% \mathrm{NPK}+50 \% \mathrm{FYM}+$ biofertilizers (Azospirillum and phosphotika)

$\mathrm{T}_{11}-50 \% \mathrm{NPK}+50 \%$ pig manure + biofertilizers (Azospirillum and phosphotika)

$\mathrm{T}_{12}-50 \% \mathrm{NPK}+50 \%$ vermicompost + biofertilizers (Azospirillum and phosphotika)

\section{Plant materials}

The variety G-4 (Bhagyalakshmi) has been developed at Regional Agricultural Research Station (RARS), Lam, Guntur; derived through selection in Thohian chilli from Sri Lanka. Plants bear narrow dark green leaves and are fairly tolerant to pests and diseases. Fruits are olive green, turn dark red on ripening. This variety is use in the experiment.

\section{Nursery raising}

The experiment was started on $9^{\text {th }}$ October, 2010. Nursery was raised under low cost polyhouse. Nursery bed was prepared by mixing FYM@ 5 Kg, SSP@ 30g and MOP@ $10 \mathrm{~g} \mathrm{~m}^{-2}$ area. It was raised $15 \mathrm{~cm}$ above the ground to avoid water logging condition. The seed were sown in line with $8-10 \mathrm{~cm}$ distance in a bed of $1 \mathrm{~m} \times 1 \mathrm{~m}$; at depth of $1 \mathrm{~cm}$. Irrigation were given right after sowing. Seed took about 10 to 15 days to germinate.
Intermittent irrigation at forth nightly interval was given till transplanting.

\section{Sampling and observation recorded}

Five plants in each plot were duly tagged for recording the observations.

\section{Yield and yield attributes}

\section{Number of fruits}

Beginning from the first harvest till final harvest the number of fruits harvested from each sample plants was recorded.

\section{Fresh weight of fruit}

Harvested fruits of each sample plants were weight from electronic weighing balance. The values obtained were recorded in grams. The average fresh weight of each single fruit from all sample plants was also recorded.

\section{Fruit length}

Fruit length was taken with the help of vernier calliper. Five representative fruits from each sample were selected for measuring fruit length. There mean values were later worked out and given in $\mathrm{cm}$.

\section{Fruit diameter}

Fruit diameter was also taken with the help of vernier calliper. Five representative fruits from each sample plants were selected for measuring fruit diameter. There mean values were later worked out and given in $\mathrm{cm}$.

\section{Yield per plant}

The total yield of each sample plants were obtained from the fresh weight of fruits harvested from each sample plants, given in grams. 


\section{Yield per plot}

Yield per plot was determined by multiplying the yield per plant with the number of plants per plot i.e., sixteen. The yield per plot was expressed in kilogram $(\mathrm{kg})$.

\section{Yield per hectare}

Yield of every plot was recorded separately and per hectare yield was computed from plot yield by the following formulae-

$\mathrm{X}=\frac{\text { Yield per plant }(\mathrm{kg}) \times 10,000}{\text { Area of the plot }\left(\mathrm{m}^{2}\right)}$

Where $\mathrm{X}$ denotes yield in $\mathrm{kg} \mathrm{ha}^{-1}$

The data obtained were expressed in quintals per hectare

\section{Quality parameters}

\section{Total Soluble Solids (TSS)}

The total soluble solids of the fruit were determined with the help of ERMA, hand Refractometer calibrated at $20^{\circ} \mathrm{C}$. The results were expressed in ${ }^{\circ}$ Brix.

\section{Vitamin C}

Fruits which were fully matured but not ripe were used for vitamin $\mathrm{C}$ analysis. Vitamin $\mathrm{C}$ 'or' Ascorbic acid content were determine by using 2, 6 - Dichlorophenol dye method as given by Rangana (1977). $2.5 \mathrm{ml}$ of fruit juice was taken in $25 \mathrm{ml}$ volumetric flask and volume made up to $25 \mathrm{ml}$ with $3 \%$ metaphosphoric acid. Than $5 \mathrm{ml}$ of the diluted juice was taken and titrated against 2, 6 Dichlorophenol indophenyl dye. The end point is light pink and colour should persist for 15 seconds. The results obtained were expressed in $\mathrm{mg} / 100 \mathrm{~g}$ of fruit juice.
The formula used were given as follows-

Titrated volume $\mathrm{x}$ Dye factor $\mathrm{x}$ Volume

(25ml) make up x 100

Vitamin $\mathrm{C}(\mathrm{mg} / 100 \mathrm{~g}$ of juice $)=$

Aliquot of extract taken for estimation $(5 \mathrm{ml}) \mathrm{x}$ volume of sample taken for estimation $(25 \mathrm{ml})$

\section{Results and Discussion}

\section{Yield and yield attributing character}

The findings of the experiment indicated beneficial effect of integrating NPK fertilization with various organic manures as well as biofertilizers on yield and yield attributing characters of chilli.

Application of $50 \%$ NPK $+50 \%$ FYM + Biofertilizers recorded maximum result in all yield attributing characters such as number of fruits (99.44), fresh weight of fruit $(3.30 \mathrm{~g})$, fruit length $(8.90 \mathrm{~cm})$ and fruit diameter $(1.20$ $\mathrm{cm})$. This result indicates positive effects of integrating NPK with manures as well as biofertilizers. This findings has close conformity with Harikrishna et al., (2002) who reported highest yield of fruits $(54.32 \mathrm{t}$ $\mathrm{ha}^{-1}$ ) with treatment of FYM $\left(25 \mathrm{tha}^{-1}\right)+75 \%$ recommended dose of NPK + Azospirillum from their study on integrated nutrient management on availability of nutrient in tomato. On the other hand, application of $100 \%$ NPK in chilli was found to produce inferior result than those treatments where manures are either applied alone or in an integrated manner.

It was found that yield attributing characters in chilli improved with application of 50\% $\mathrm{NPK}+50 \% \mathrm{FYM}+$ Biofertilizers which was also found to have positive corresponding effect on yield parameters such as fruit yield per plant $(328.57 \mathrm{~g})$, yield per plot $(5.26 \mathrm{~kg})$ as well as projected yield per hectare (194.70 $\mathrm{q} \mathrm{ha}^{-1}$ ). Integrating 50\% NPK $+50 \%$ 
Vermicompost + Biofertilizers $\left(\mathrm{T}_{12}\right)$ has shown competitive result in yield and yield attributing parameters and was found to be superior over other treatments except for $50 \%$ $\mathrm{NPK}+50 \% \mathrm{FYM}+$ Biofertilizers integration. However, $\mathrm{T}_{12} \quad(50 \% \mathrm{NPK}+50 \%$ Vermicompost) + Biofertilizers) was found to be at par with $50 \%$ NPK $+50 \%$ Pig manure + Biofertilizers $\left(\mathrm{T}_{11}\right)$. These superior effects of integrating $50 \%$ NPK $+50 \%$ (FYM 'or' Pig manure 'or' Vermicompost) + Biofertilizers (Azospirillum + Phosphotika) over other treatments may be due to better integration effect of FYM 'or' Pig manure 'or' Vermicompost with biofertilizers.

Maximum yield per plant (328.57 g), yield per plot $(5.26 \mathrm{~kg})$ as well as projected yield per hectare (194.70 q) were recorded highest in the treatment combination of $50 \% \mathrm{NPK}+$ $50 \%$ FYM + Biofertilizers. This can be due to corresponding response to increased yield attributing characters attained previously under this treatment combination. This has conformity with Ravanappa et al., (1997) who reported that in chillies higher yield can be obtained due to higher number of fruits with improved fruit yield parameters such as width, volume and weight. Again this conclusion has conformity with the findings of Sajan et al., (2002) who reported that in chilli cv. Byadagi Dabba, plants inoculated with Azotobacter, Azospirillum, PSB and VAM in combination with $75 \% \mathrm{NP}+100 \%$ $\mathrm{K}$ results in $35 \%$ more fruit per plant (11.38) and $45 \%$ more dry fruit yield $2.27 \mathrm{t} \mathrm{ha}^{-1}$. On the other hand, Sudhakar and Purushotham (2008) revealed that tomato plants with RDF + Azotobacter @ $15 \mathrm{~kg} \mathrm{ha}^{-1}$ recorded maximum number of fruits plant ${ }^{-1}$ (25.75), yield plant $^{-1}(2029.5 \mathrm{~g})$ and yield hectare ${ }^{-1}$ (751.8 q) while plants with RDF + PSB @ 5 $\mathrm{kg} \mathrm{ha}{ }^{-1}$ exhibited maximum fruit weight $(85.17 \mathrm{~g})$ and fruit size $\left(22.47 \mathrm{~cm}^{2}\right)$. Similarly, Chumyani et al., (2012) and Vimera et al., (2010) also conducted an experiment on integrated nutrient management and found that $50 \% \mathrm{NPK}+50 \% \mathrm{FYM}+$ Biofertilizers recorded maximum yield and yield attributes in tomato and king chilli.

\section{Quality attributes}

The findings of the experiment indicated beneficial effect of integrating NPK fertilization with various organic manures as well as biofertilizers on quality attributing characters of chilli.

Quality of chilli is generally evaluated in terms of TSS and vitamin C. It is observed that combination treatment of $50 \% \mathrm{NPK}+$ $50 \%$ FYM + Biofertilizers significantly increased the TSS $\left(5.10^{\circ}\right.$ Brix $)$ and ascorbic acid $(247.16 \mathrm{mg} / 100 \mathrm{~g})$. Similar findings were also reported by Mahmood and Amara (2000) who found that biofertilizers application combined with $50 \%$ RDF gave the highest TSS and vitamin $\mathrm{C}$ content as well as nutrient content of fruit. Rofi et al., (2002) also concluded that application of $50 \%$ recommended dose of FYM @ $12.5 \mathrm{t} \mathrm{ha}^{-1}$ along with $50 \%$ of RDF (100:50:50 kg NPK $\left.\mathrm{ha}^{-1}\right)$ resulted in the highest TSS $(6.08 \%)$ and ascorbic acid content (26.76 mg/100g)., Ghoname and Shafeek (2005) in sweet pepper (Capsicum annum L.) also reported favourable response of vitamin $\mathrm{C}$ to integrated nutrient management. Similarly, Sentiyangla et al., (2010) and Chumyani et al., (2012) observed that application of 50\% NPK + 50\% FYM + Biofertilizers recorded maximum TSS and vitamin $\mathrm{C}$ in radish and tomato. Vimera et al., (2010) also reported maximum vitamin $\mathrm{C}(117 \mathrm{mg} / 100 \mathrm{~g})$ by the application of $50 \% \mathrm{NPK}+50 \% \mathrm{FYM}+$ Biofertilizers in king chilli.

The comparative higher level of both TSS and vitamin $\mathrm{C}$ upon treatments with integration may be due to action of specific soil nutrients which may be made more readily available 
into the soil for plant absorption as a result of mineral fertilizer + lone organic manure 'or' with biofertilizers integration effect which in term may activate specific enzymes for the synthesis of these compounds. It is therefore certain that specific nutrients in soil play a vital role in determining these quality parameters.

\section{References}

Anonymous, (2004) The Hindu Survey of India Agriculture, Deccan Exhibitions Private Limited, Pune.

Anonymous, (2005) Agriculture, Centre for Monitoring Indian Economy, Mumbai. Pp. 229- 232.

Chaubey, K. A., Kumar, R. and Shahi, U. P. (2004). Integrated Plant Nutrient Management (IPNM): A need for future agriculture. Indian Farmer's Digest: 14 -17 .

Chumyani; Kanaujia, S. P., Singh, A. K. and Singh, V. B. (2012). Effect of integrated nutrient management on growth, yield and quality of tomato (Lycopersicon esculentum mill.). Journal of Soil and Crops 22(1): 5 - 9.

Ghoname, A. and Shafeek, M. R. (2005). Growth and productivity of sweet pepper (Capsicum annum L.) grown in plastic house as effected by organic, mineral and bio-N-fertilizers. Journal of Agronomy 4: 369-372.

Harikrishna, B. L., Channal, H. T., Hebsur, N. S., Dharmatti, P. R. and Sarangamathi, P. A. (2002). Integrated nutrient management on availability of nutrients uptake and yield of tomato. Karnataka Journal of Agriculture Sciences 15: 275 -278 .

Mahmood, H. A. F. and Amara, M. A. T. (2000). Response of tomato to biological and mineral fertilizers under calcareous soil conditions. Bulletin of
Faculty Agriculture, Cario University 51: $151-174$.

Raju, K. V. and Luckrose, C. K., 1991, Trend in area, production and impact of chillies from India. Agricultural Situation in India, 45: 762-772.

Rangana, S. (1977). Manual of Analysis for Fruit and Vegetable Products. Tata Mc Graw Hill Publishing Co. Ltd., New Delhi.

Revanappa; Nalawadi, U. G. and Madalageri, M. B. (1997). Influence of nitrogen on fruit parameters and yield parameters in green chilli genotypes. Karnataka Journal of Agriculture Sciences 10: 1060 - 1064.

Rofi, M., Narwadkar, P. R., Prabu, T. and Sajindranath, A. K. (2002). Effect of organic and inorganic fertilizers on yield and quality of tomato. Journal of Soils and Crops 12: $167-169$.

Roy, R. N. and Ange, A. L. (1991). Integrated plant nutrient system (IPNS) and sustainable agriculture. Proceeding of Annual Siminar, FAI, New Delhi. pp. $\mathrm{SV} / 1-1-\mathrm{SV} / 1-12$.

Sajan, K. M., Gowda, K. K., Kumar, S. N. and Sreeramu, B. S. (2002). Effect of bio-fertilizers on growth and yield of chilli (Capsicum annum L.) cv. Byadagi Dabba at different levels of nitrogen and phosphorus. Journal of Spices and Aromatic Crops. 11: 58- 61.

Sentiyangla, P., Kanaujia, S. P., Singh, A. K. and Singh, V. B. (2010). Integrated nutrient management for quality production of radish (Raphanus sativus L.) in acid Alfisol. Journal of Soils and Crops 20: $1-9$.

Sudhakar, P. S. and Purushotham, K. (2008). Studies on the effects of biofertilizers on growth, yield and quality of tomato. The Orissa Journal of Horticulture 36: $93-96$.

Tilak, K. V. B. R. and Singh, G. (1996). Integrated Nutrient Management in 
sustainable agriculture. Fertilizer News 41: $29-35$.

Vimera, K., Kanaujia, S. P., Singh, V. B. and Singh, P. K. (2010). Integrated nutrient management for quality production of king chilli (Capsicum chinense Jackquin) in an acid alfisol. Journal of the Indian Society of Soil Science Vol. 60, No. 1.

\section{How to cite this article:}

Samsangheile Nchang, S.P. Kanaujia, Santosh Lal, Vinit Kumar Meena and Babu Singh Tanwar. 2018. Studies on Integrated Nutrient Management on Yield and Quality of Chilli (Capsicum annum L.). Int.J.Curr.Microbiol.App.Sci. 7(09): 2053-2059. doi: https://doi.org/10.20546/ijcmas.2018.709.250 